\title{
Role of Laparoscopic Sleeve Gastrectomy (LSG) for Management of Obese Patients with Type 2 Diabetes Mellitus- Single Center Study
}

\author{
MOHAMED ABOUL NAGA, M.D. and KAMAL MAMDOUH, M.D. \\ The Department of General Surgery, Faculty of Medicine, Ain Shams University, Cairo
}

\begin{abstract}
Background: Laparoscopic Sleeve Gastrectomy (LSG) has become one of the commonest bariatric procedures done for management of obese patients. Although Laparoscopic Roux-en-Y Gastric Bypass (LRYGB) has well documented positive clinical influence on type 2 diabetes, the role of LSG in diabetes treatment is still questionable. In this study we want to present our experience in management of diabetes with LSG.

Methods: Between September 2014 and June 2016, fifty patients were enrolled in our prospective study at Department of Surgery, Ain Shams University assessing the effect of LSG on morbid obese patients with Type 2 Diabetes Mellitus (T2DM). All patients were monitored for weight loss and improvement of T2DM markers; Fasting Blood Glucose (FBG), Postprandial Plasma Glucose (PPG) and HbAlc at 3, 6 and 12 months follow-up post-operative.

Results: There was a highly significant difference between $\mathrm{BMI}$ at baseline and at 12 months after operation, resolution of type 2 diabetes mellitus occurred in $70 \%$ of patients evident by normalization of $\mathrm{HbA} 1 \mathrm{c}(5.6 \%)$ and stopping all medications, and improvement occurred in $10 \%$ of patients evident by $\mathrm{HbA} 1 \mathrm{c}$ value of $6.5 \%$ without medication.

Conclusion: Laparoscopic sleeve gastrectomy is simple and effective surgical procedure to achieve a significant weight loss and control of type 2 diabetes mellitus which starts in the early post-operative period. There is significant reduction in the diabetes medications hence the cost of diabetes treatment and improvement of the quality of life.
\end{abstract}

Key Words: Sleeve gastrectomy - Morbid obesity - Type 2 diabetes mellitus.

\section{Introduction}

OBESITY prevalence is increasing around the world, and now around a billion adults are obese [1]. Type 2 diabetes and glucose metabolism abnormalities are one of the most important effects of morbid obesity which lead to severe and chronic reduction in quality of health. High effectiveness

Correspondence to: Dr. Mohamed Aboul Naga,

The Department of General Surgery, Faculty of Medicine, Ain Shams University, Cairo of bariatric therapy for weight reduction and treatment of comorbidities has been proven in numerous studies [2]. Diabetes mellitus is a chronic disease, that has reached epidemic proportions worldwide and its prevalence continues to increase. The prevalence of diabetes for all age-groups worldwide was estimated to be $2.8 \%$ in 2000 and $4.4 \%$ in 2030. In the year 2000 there were approximately 171 million people aged 35 to 64 years with diabetes throughout the world; by 2030, there will be 366 million [3]. The relationship between obesity and Type 2 Diabetes Mellitus (T2DM) is well known, and up to one-third of patients presenting for bariatric operation are known to be diabetic [4]. There is increased risk of T2DM with increase in Body Mass Index (BMI) from 2\% among those with of BMI 25 to $29.9 \mathrm{~kg} / \mathrm{m}^{2}$ to $13 \%$ if BMI is $>35 \mathrm{~kg} / \mathrm{m}^{2}$. Patients with a BMI $>35 \mathrm{~kg} / \mathrm{m}^{2}$ have 40 times greater risk than people with lower BMI [5]. In recent years, Laparoscopic Sleeve Gastrectomy (LSG) has become one of the most commonly used primary bariatric procedure for morbid obesity [6] Numerous authors strive to prove that effect of LSG on type 2 diabetes treatment is as good as Laparoscopic Roux-en-Y Gastric Bypass (LRYGB), which was known as a "gold standard" for diabetic patients. Potential mechanisms of diabetes remission and improvement in glucose homeostasis after LSG are the main topic of recent studies, yet its results are still unclear [7]. In this study we want to present our experience in management of diabetes with LSG in obese patients.

\section{Patients and Methods}

This study was carried out in Ain Shams University Hospitals during the period starting from September 2014, till June 2016. This study was designed as a prospective interventional study, to evaluate the effect of Laparoscopic Sleeve Gastrectomy on obese patients with type 2 diabetes 
mellitus. Fifty patients were included in this study. This study included both males $(\mathrm{n}=12)$ and females $(\mathrm{n}=38)$, aged $\geq 18$ year old, with BMI $\geq 35 \mathrm{~kg} / \mathrm{m}^{2}$, associated with obesity related co-morbidities (Table 1) (including type 2 diabetes mellitus); (where diabetes mellitus is diagnosed when: Symptoms of diabetes and a random blood sugar of 200 $\mathrm{mg} / \mathrm{dl}(11.1 \mathrm{mmol} / \mathrm{L})$ or higher, or a fasting blood sugar level of $126 \mathrm{mg} / \mathrm{dl}(7.0 \mathrm{mmol} / \mathrm{L})$ or higher, or a $\mathrm{HbA} 1 \mathrm{c}$ of 6.5 percent or higher), or who failed $\geq 6$ months of organized non-surgical weight loss attempts.

\section{Operative technique:}

The operations were performed laparoscopically under general anesthesia using the French position (the surgeon standing between the patient's legs). Each procedure required 5 trocars. Pneumoperitoneum was established by visi-port just above and to the left of the umbilicus and maintained at a pressure of $18 \mathrm{mmHg}$. Dissection started on the greater curvature, $4 \mathrm{~cm}$ from the pylorus. The gastrocolic ligament along the greater curvature of the stomach was opened using an impedance coagulator (LigaSure Blunt Tip Laparoscopic Sealer/ Divider) and was freed as far as the cardio esophageal junction at the root of the left pillar of the hiatus. The short gastric vessels close to the spleen were carefully coagulated separately. A calibration tube using a 36-F was then inserted transorally into the stomach by the anesthesiologist and directed toward the antrum $4 \mathrm{~cm}$ from the pylorus. A laparoscopic linear stapler was used to divide the stomach parallel to the orogastric tube along the lesser curvature. The instrument was fired, reloaded, and the procedure was repeated; a maximum 6 cartridges were used to staple the antrum, the body, and fundus of the stomach.

\section{Outcome:}

Resolution of T2DM were defined as a $\mathrm{HbA} 1 \mathrm{C}$ value of $5.6 \%$ and improvement as a $\mathrm{HbA} 1 \mathrm{C}$ value of $6.5 \%$ for both without the use of hypoglycemic oral medication or insulin at 12 months follow-up while failure was defined as persistence of symptoms of T2DM and failure to achieve adequate glycemic control without medications.

\section{Statistical analysis:}

The collected data was revised, coded, tabulated and introduced to a PC using Statistical package for Social Science (IBM Corp. Released 2011. IBM SPSS Statistics for Windows, Version 20.0. Armonk, NY: IBM Corp). Data was presented and suitable analysis was done according to the type of data obtained for each parameter.
Table (1): Description of personal and medical characteristics among study cases.

\begin{tabular}{|c|c|c|c|c|c|c|}
\hline & Mean & $\pm \mathrm{SD}$ & Min Max & Median & $\mathrm{IQ}$ & $\mathrm{R}^{*}$ \\
\hline Age & 35.22 & 8.33 & 18.060 .0 & 35.5 & 29 & 14 \\
\hline Duration of T2DM (years) & 9.82 & 9.23 & 1.0040 .0 & 6.0 & 3 & 15 \\
\hline $\begin{array}{l}\text { Sex: } \\
\text { - Male (n \%) } \\
\text { - Female (n \%) }\end{array}$ & $\begin{array}{l}12 \\
38\end{array}$ & $\begin{array}{l}24.0 \% \\
76.0 \%\end{array}$ & & & & \\
\hline $\begin{array}{l}\text { Co-morbidities: } \\
\text { - None (n \%) } \\
\text { - HTN (n \%) } \\
\text { - Dyslipidaemia (n \%) } \\
\text { - HTN/dyslipidaemia (n \%) }\end{array}$ & $\begin{array}{l}15 \\
2 \\
22 \\
11\end{array}$ & $\begin{array}{l}30.0 \% \\
4.0 \% \\
44.0 \% \\
22.0 \%\end{array}$ & & & & \\
\hline
\end{tabular}

\section{Results}

For the study cases, the mean height was 172.18 $\pm 6.35 \mathrm{~cm}$. The mean baseline weight was 126.84 $\pm 9.93 \mathrm{~kg}$. On follow-up, the mean weight was $107.86 \pm 7.85 \mathrm{~kg}, 101.34 \pm 7.68 \mathrm{~kg}$, and $94.26 \pm 6.64 \mathrm{~kg}$, for the following 3,6, and 12 months respectively. The mean BMI was $42.77 \pm 2.39$, and $31.77 \pm 0.98$ for the baseline and the 12 months values respectively. Therefore, the mean EWL \% was $61.48 \pm$ 0.99 (Table 2).

In our study we observed a dramatic improvement in the biomarkers of diabetes mellitus through our follow-up at 3,6 and 12 months post-operative via measuring FBG, PPG and $\mathrm{HbA} 1 \mathrm{c}$ with no statistical difference as regard other co-morbidities.

As regard the mean FPG, it was $161.92 \pm 16.25$ $\mathrm{mg} / \mathrm{dl}, 127.46 \pm 15.59 \mathrm{mg} / \mathrm{dl}, 117.20 \pm 19.02 \mathrm{mg} / \mathrm{dl}$, and $102.84 \pm 25.17 \mathrm{mg} / \mathrm{dl}$, for baseline, 3,6 , and 12 months respectively. While the mean PPG, it was $232.62 \pm 19.89 \mathrm{mg} / \mathrm{dl}, 178.94 \pm 23.16 \mathrm{mg} / \mathrm{dl}, 167.78$ $\pm 23.90 \mathrm{mg} / \mathrm{dl}$, and $149.54 \pm 32.74 \mathrm{mg} / \mathrm{dl}$, for baseline, 3,6 , and 12 months respectively.

As regard the mean $\mathrm{HbA1c}$, it was $9.18 \pm 1.56 \%$, $7.92 \pm 1.72 \%, 6.83 \pm 1.69 \%$, and $5.93 \pm 1.39 \%$, for baseline, 3, 6, and 12 months respectively. As shown in (Table 4$), 10$ (20\%) of the study group, showed no change as regards diabetic profile. However, 5 (10\%) patients were improved, and 35 (70\%) patients were cured (Table 3).

Table (2): Description of anthropometric measures at baseline and at follow-up among study cases.

\begin{tabular}{llccc}
\hline & Mean & \pm SD & Minimum & Maximum \\
\hline Height $(\mathrm{cm})$ & 172.18 & 6.35 & 163.00 & 188.00 \\
Weight $(\mathrm{kg})$ baseline & 126.84 & 9.93 & 108.00 & 156.00 \\
Weight after 3 months & 107.86 & 7.85 & 93.00 & 130.00 \\
Weight after 6 months & 101.34 & 7.68 & 87.00 & 124.00 \\
Weight after 12 months & 94.26 & 6.64 & 82.00 & 113.00 \\
BMI baseline & 42.77 & 2.39 & 39.71 & 50.93 \\
BMI after 12 months & 31.77 & 0.98 & 30.45 & 34.89 \\
EWL \% & 61.48 & 0.99 & 60.00 & 63.00 \\
\hline
\end{tabular}


Table (3): Description of blood glucose measures at baseline and at follow-up among study cases.

\begin{tabular}{lllll}
\hline & Mean & \pm SD & Minimum & Maximum \\
\hline FPG baseline & 161.92 & 16.25 & 131.00 & 194.00 \\
FPG after 3 months & 127.46 & 15.59 & 89.00 & 154.00 \\
FPG after 6 months & 117.20 & 19.02 & 76.00 & 159.00 \\
FPG after 12 months & 102.84 & 25.17 & 65.00 & 167.00 \\
PPG baseline & 232.62 & 19.89 & 202.00 & 268.00 \\
PPG after 3 months & 178.94 & 23.16 & 132.00 & 241.00 \\
PPG after 6 months & 167.78 & 23.90 & 132.00 & 233.00 \\
PPG after 12 months & 149.54 & 32.74 & 103.00 & 277.00 \\
HbA1c baseline & 9.18 & 1.56 & 6.60 & 11.90 \\
Hb A1c after 3 months & 7.92 & 1.72 & 5.40 & 11.80 \\
Hb A1c after 6 months & 6.83 & 1.69 & 5.50 & 12.30 \\
Hb A1c after 12 months & 5.93 & 1.39 & 5.10 & 10.30 \\
& & & & \\
DM: & & & & \\
$\quad$ No change (n \%) & 10 & $20.0 \%$ & & \\
Improved (n \%) & 5 & $10.0 \%$ & & \\
Cured (n \%) & 35 & $70.0 \%$ & & \\
\hline
\end{tabular}

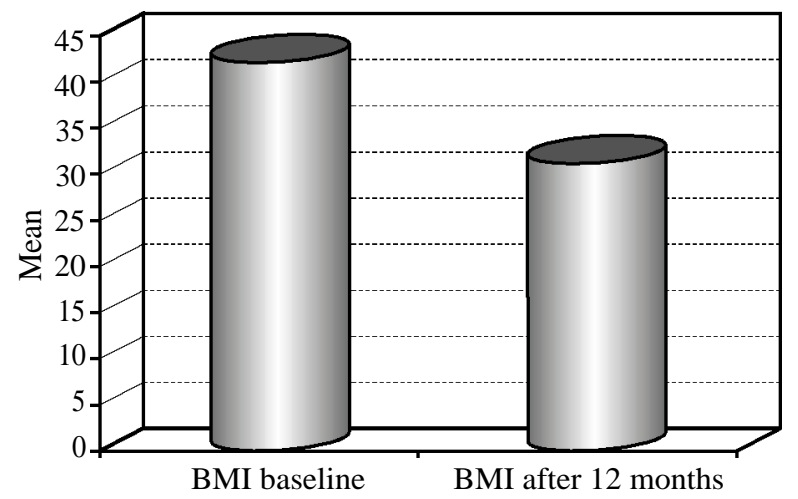

Chart (1): BMI at baseline and 12 months.

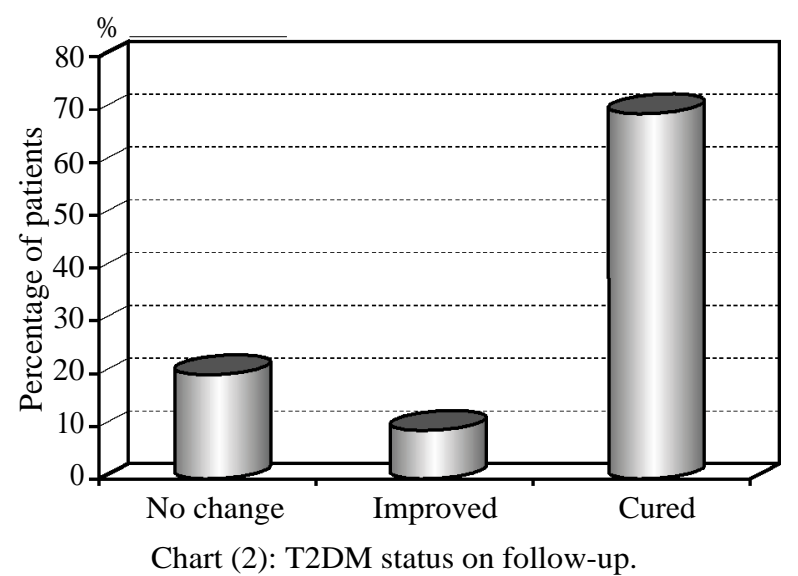

Discussion

LRYGB and LSG are the most common bariatric surgeries worldwide. The role of bariatric surgery in management of morbid obesity is well established. The effect of bariatric surgeries on weight loss is important as well as its impact on co-morbidities, especially type 2 diabetes. In the age of bariatric surgery, type 2 diabetes can be viewed as a curable disease. Bariatric surgery has been confirmed to be beneficial in remission of abnormalities in glucose homeostasis [8]

In opposition to LRYGB, mechanisms of diabetes remission after LSG are not well-defined. The Glucagon-Like Peptide 1 (GLP-1) play the key-role in changes of glucose metabolism and it is responsible for improvement of glucose homeostasis after LRYGB. After LSG the level of GLP-1 rises as well, thus it has been suggested to contribute to potential improvements in diabetes remission [9]. In previous studies we noticed the same relations between gut hormones after LSG [10]

Revising the literature, the rate of loss of excess weight at one year is $62 \%$, as reported by Todkar et al., [11], and $77.1 \%$ as reported by Wang et al., [12]. The mean EWL\% in our study is $61.48 \pm 0.99$ at 12 months, which is significant and is consistent with the other studies. Similarly, the mean BMI also reduced substantially $\left(31.77 \mathrm{~kg} / \mathrm{m}^{2}\right)$ in accordance with the earlier studies, $\left(27.9 \mathrm{~kg} / \mathrm{m}^{2}\right.$, as reported by Wang et al., several studies show the difference in therapeutic effects for different BMIs, where patients with lower BMI $\left(<40 \mathrm{~kg} / \mathrm{m}^{2}\right)$ can achieve a higher $\%$ of EWL than patients with higher BMI $\left(>40 \mathrm{~kg} / \mathrm{m}^{2}\right)$ [12] . It is expected that the loss of excess weight may be even more if patients follow the nutritional guidelines strictly, which is high-protein, low- calorie diet and regular exercise [13]

Significant improvement of plasma glucose level control, and/or resolution of type 2 diabetes mellitus (as evident by diabetic markers like fasting as well as post prandial plasma glucose levels, and $\mathrm{HbA} 1 \mathrm{c})$, is commonly observed after LSG [14] After 12 months, a remission of type 2 diabetes mellitus after LSG was $57.7 \%$ as reported by Peterli et al., [15], $80.9 \%$ as reported by Abbatini et al., [16], 78.6\% as reported by Yang et al., [17], and $84.6 \%$ as reported by Vidal et al., [19]. In our study, resolution of type 2 diabetes mellitus occurred in $70 \%$ of patients $(n=35)$, and improvement occurred in $10 \%$ of patients $(n=5)$.

Abbatini et al., reported a mean FPG level of $195 \mathrm{mg} / \mathrm{dl}$ and $97 \mathrm{mg} / \mathrm{dl}$, at baseline and 12 months post-operative respectively [16]. Yang et al., also reported improvement in FPG compared to baseline throughout the 12-months follow-up period. FPG was seen to reduce from diabetic levels $(180 \mathrm{mg} / \mathrm{dl})$ to $106 \mathrm{mg} / \mathrm{dl}$ [17]. In our study, the mean baseline FPG is $161 \mathrm{mg} / \mathrm{dl}$, while the mean FPG at 12 months post-operative is $102 \mathrm{mg} / \mathrm{dl}$. 
According to Kumar et al., the mean PPG was $208 \mathrm{mg} / \mathrm{dl}$, and $167 \mathrm{mg} / \mathrm{dl}$, at baseline and 12 months post-operatively [19]. In our study, the mean PPG declined from $232 \mathrm{mg} / \mathrm{dl}$ at baseline to $149 \mathrm{mg} / \mathrm{dl}$ at 12 months post-operatively.

HbA1c followed a similar pattern to that of both FPG and PPG. A significant reduction was observed from baseline (8.5) to 3 months (7.0) and continued to decrease throughout the follow-up period until stabilizing at the 12 months (5.9), as reported by Yang et al., [17]. Similarly, in our study, $\mathrm{HbA1c}$, demonstrated a significant reduction from 9.1 at baseline, to 7.9 at 3 months and continued to decrease to 5.9 at 12 months post-operatively.

\section{Conclusion:}

LSG is an accepted procedure for control of obesity and obesity related co-morbidity like type $2 \mathrm{DM}$ with adequate remission of the disease.

\section{References}

1- SARKHOSH K., BIRCH D.W., SHI X., GILL R.S. and KARMALI S.: The impact of sleeve gastrectomy on hypertension: A systematic review. Obes. Surg., 22 (5): 832-7, 2012.

2- SUNDBOM M.: Laparoscopic revolution in bariatric surgery. World J. Gastroenterol., 20: 15135-43. 10.3748/ wjg.v20.i41.15135, 2014.

3- WILD S., ROGLIC G. and GREEN A.: Global prevalence of diabetes: Estimates for the year 2000 and projections for 2030 Diabetes Care, 27: 1047-53, 2017.

4- RESIDORI L., GARCIA-LORDA P., FLANCBAUM L., PI-SUNYER F.X. and LAFERRERE B.: Prevalence of co-morbidities in obese patients before bariatric surgery: Effect of race. Obes. Surg., 13: 333-40, 2003.

5- BUCHWALD H., ESTOK R., FAHRBACH K., et al.: Weight and type 2 diabetes after bariatric surgery: Systematic review and metaanalysis. Am. J. Med., 122: 24856, 2009.

6- MATLOK M., PEDZIWIATR M., MAJOR P., et al.: One hundred seventy-nine consecutive bariatric operations after introduction of protocol inspired by the principles of enhanced recovery after surgery (ERAS $\AA$ ) in bariatric surgery. Med. Sci. Monit., 21: 791-7. 10.12659/MSM. 893297, 2015.

7- MURPHY R., EVENNETT N.J., CLARKE M.G., et al.: Sleeve gastrectomy versus Roux-en-Y gastric bypass for type 2 diabetes and morbid obesity: Double-blind randomised clinical trial protocol. B.M.J. Open, 6: e011416. 10.1136/bmjopen-2016-011416, 2016.

8- FRIED M., YUMUK V., OPPERT J.M., et al.: Interdisciplinary European guidelines on metabolic and bariatric surgery. Obes. Surg., 24: 42-55, 2014.
9- GARIBAY D., McGAVIGAN A.K., LEE S.A., et al.: RCell Glucagon-Like Peptide-1 Receptor Contributes to Improved Glucose Tolerance After Vertical Sleeve Gastrectomy. Endocrinology, 157: 3405-9, 2016.

10- MAJOR P., MATLOK M., P EDZIWIATR M., et al.: Changes in levels of selected incretins and appetitecontrolling hormones following surgical treatment for morbid obesity. Wideochir. Inne. Tech. Maloinwazyjne, 10: 458-65, 2015.

11- TODKAR J.S., SHAH S.S. and SHAH P.S.: Long-term effects of laparoscopic sleeve gastrectomy in morbidly obese subjects with type 2 diabetes mellitus. Surgery for Obesity and Related Diseases, 6: 142-5, 2015.

12- WANG X., CHANG X., GAO L., ZHENGA C., ZHAO X., YIN K. and FANG G.: Effectiveness of laparoscopic sleeve gastrectomy for weight loss and obesity-associated co-morbidities: A 3- year outcome from Mainland Chinese patients, Surg. Obes. Relat. Dis., 12: 1305-11, 2016.

13- MAJOR P., MICHAL W., MICHAL P., PIOTR M., MAGDALENA P. and ANDRZEJ B.: Laparoscopic sleeve gastrectomy for the treatment of diabetes mellitus type 2 patients-single center early experience, Gland Surg., 5: 465-72, 2016

14- GILL R.S., BIRCH D.W. and SHI X.: Sleeve gastrectomy and type 2 diabetes mellitus: A systematic review. Surgery for Obesity and Related Diseases, 6: 707-13, 2016.

15- PETERLI R., BORBELY Y., KERN B., GASS M., PETERS T., THURNHEER M., SCHULTES B., LAEDERACH K., BUETER M. and SCHIESSER M.: Early results of the Swiss Multicentre Bypass or Sleeve Study (SMBOSS): A prospective randomized trial comparing laparoscopic sleeve gastrectomy and Roux-en-Y gastric bypass. Ann. Surg., 258: 690-4, 2013.

16- ABBATINI F., RIZZELLO M., CASELLA G., ALESSANDRI G., CAPOCCIA D., LEONETTI F. and BASSO N.: Long-term effects of laparoscopic sleeve gastrectomy, gastric bypass, and adjustable gastric banding on type 2 diabetes, Surg. Endosc., 24: 1005, 2015.

17- YANG J., WANG C., CAO G., YANG W., YU S., ZHAI H. and PAN Y.: Long-term effects of laparoscopic sleeve gastrectomy versus roux-en-Y gastric bypass for the treatment of Chinese type 2 diabetes mellitus patients with body mass index $28-35 \mathrm{~kg} / \mathrm{m}$. B.M.C. Surg., 15: 88 , 2015 .

18- VIDAL J., IBARZABAL A. and NICOLAU J.: Shortterm effects of sleeve gastrectomy on type 2 diabetes mellitus in severely obese subjects. Obesity Surgery, 17: 1069-74, 2016.

19- KUMAR S., ANSARI A., VERMA U., KUMAR N. and DIXIT P.: Weight Loss and Type 2 Diabetes Control after Laparoscopic Sleeve Gastrectomy in an Early PostOperative Period-A Prospective Cohort Study, Hellenic Journal of Surgery, 88: 5, 329-35, 2016. 


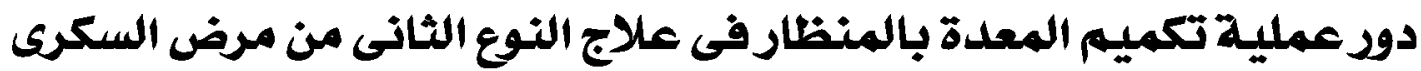

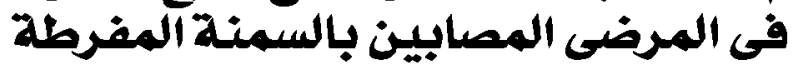

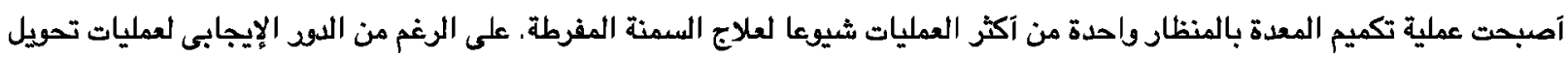

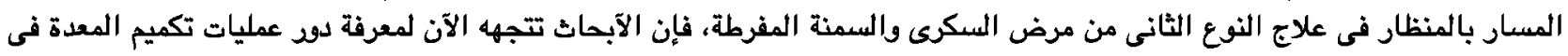

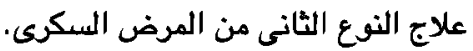

الهدف من هذه الدراسة هو معرفة دود عمليات تكميم المعدة بالهنظار فى علاج النوع الثانى من المرض السكرى فى المرضى المصابين بالسمنة المفرطة.

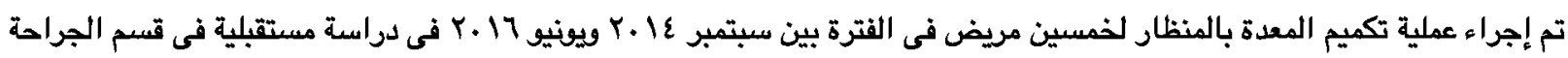

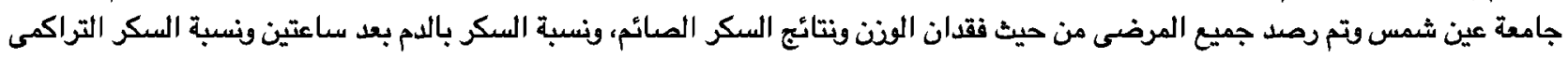
وذلك من خلال متابعة المرضى بعد ثلاثة وستة أشهر من إجراء العملية وآيضا بعد سنة.

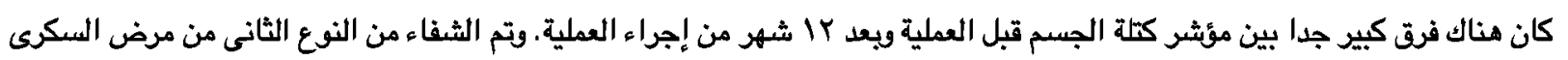

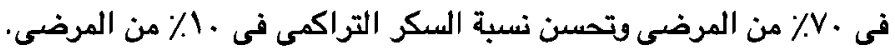
وبالتالى فإن عملية تكميم المعدة بالمنظار هى عمليات بسيطة وفعالة لتحقيق إنخفاض ملحوظ فى المذن بالإضافة إلى تحسن ملحوظ فى

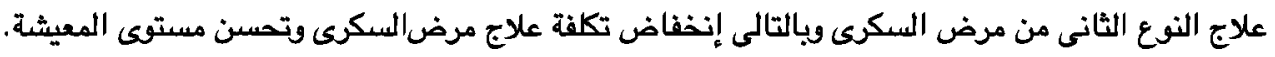

